\title{
Sentences with the 'State of Nature' Meaning in the Russian Language: Cognitive and Linguocultural Aspects of the Analysis
}

\author{
Olga Alexandrovna Selemeneva
}

Yelets State Bunin University, 28 Kommunarov St., Yelets, 399770, Lipetsk Region, Russian Federation

\author{
Doi:10.5901/mjss.2015.v6n5s4p235
}

\section{Abstract}

The article deals with the sentences denoting the 'state of nature' which are treated as bilateral units. In view of the approach to the sentences from the specified semantics as linguistic units with a symbolic nature, the author reveals a list of structural schemes, as a means of verbalization of the concept denoting the 'state of nature' in the Russian language. The 'state of nature' concept itself is qualified as a quantum of knowledge storage about extra linguistic situations of the same type, categorized by human consciousness. The content of this concept is structured in the form of the field represented by a number of cognitive characteristics, ranked by brightness index and distributed in nuclear and peripheral zones. As the speech units sentences with the 'state of nature' meaning are treated as statements which do not constitute a homogeneous group either by the process of perception by an Observer or the way of the state manifestation. The collection of such statements accumulates in their semantics archaic representation of the nature of the Slavs and the key invariant ideas of that fragment of Russian language worldview, which represents the 'nature - state of nature' extra linguistic situation.

Keywords: statement, 'state of nature' concept, cognitive feature, structural scheme of the simple sentence, Observer, language worldview, archaic character, key ideas, metaphor.

\section{Introduction}

In the world science of syntax the basic principles of modern linguistics are the principle of anthropocentrism, the explanatoriness, expansionism, semantic-centrism and others - determine the fruitful development of the so-called active syntax, primarily represented by the semantic and pragmatic syntax. At the end of the 20th - beginning of the 21st century the ideas of the active syntax are stimulated by the development of such areas as cognitive linguistics and linguocultural studies. The main vectors of these research areas are related to the study of the units of the mental sphere (concepts) with accentuation of their value and cultural component, or its lack and the language worldview as a set of people's representations about reality fixed in language units.

The relevance of the study of the fragment of the language worldview, representing different states of nature, is determined by several linguistic and extra linguistic factors. First of them is the under-investigation of this phenomenon both in Russian studies and foreign linguistics, and this is despite the fact that the category of state itself has attracted the interest of researchers and it is treated as a hyper category possessing an ontological status and used by cognitive system to represent the world (Le Ny, 1979; Jackendoff, 1983; Bodeh, 2004; Yakovleva, 2004 and others). Secondly, it is due to the ability of nature combined with the cultural and community traditions, physiological and anthropological features to form the basis of the national character, mentality, temperament (Rzhepyanskaya, 2010). Thirdly, it derives from the ability to trace the connection of nominative and cognitive activities of a man as they relate to the syntax based on the interaction of theory of nomination with cognitive linguistics and linguo-cultural studies. The latter, in our opinion, is particularly important, because the syntax is "rails on which the train of cognition is moving" (Norman, 2013). The role of syntax in the cognition process deserves attention if only because the study of ways of thinking about the world in their relation to the syntactic structure of the language allows looking under a new angle at the problem of the structural and semantic organization of the sentence and its typology, which has had a long history of studying.

\section{Methodology}

Our study was carried out on the material of the author's filing examples (including over 9,000 examples), which are samples of statements with the 'state of nature' meaning from the fiction by Russian writers of the $19^{\text {th }}-20^{\text {th }}$ centuries (I. A. Bunin, I. A. Goncharov, F. M. Dostoevsky, A. I. Kuprin, K. G. Paustovsky, L. N. Tolstoy, I. S. Turgenev, A. P. Chekhov and others.). The nature of the material under study led to the use of the totality of scientific and special 
methods: descriptive and analytical methods with observation techniques, interpretation and systematization; the method of contextual analysis to identify the contextual features of the meaning realization of separate words in the text; synchronous and diachronic method to compare the statements extracted from the texts belonging to different historical periods. We also used a linguo-cognitive analysis technique, based on the interaction of logical and semantic-cognitive approach aimed at identifying the cognitive features of the investigated concept.

\section{The Basic Part}

The currently dominant cognitive hypothesis attributes to human behavior the ability to represent the world around us in some way (Searle, 1983). The language conveys the information about the outside world with its realities and the relationship between them. Phonetic, lexical, derivational, morphological and syntactic subsystems, each of which has an internal structure and elements, are singled out in the various models of the language (models of level, field, multi-layer, etc.). The large number of syntactic objects led linguists to search for that unit of the syntactic subsystem, which could form the basis of the study. This original unit was a simple sentence. Such a choice is favored by the fact that simple sentences, as opposed to complex sentences and phrases, are present in all world languages.

The sentence as a basic unit of the syntactic subsystem contains information about any extra-linguistic situation, a certain "segment" of reality. As the world is presented in the language indirectly, through thought, then the situations of reality being reflected in the human mind create some mental images. The images of totality of situations of extra linguistic reality that have arisen as a result of categorizing and classifying activity of the human mind, are called typical propositions and considered as a certain type of concept along with the idea, the concept, the frame, the script, etc. in cognitively oriented syntax (Boldyrev, 2002). Structural schemes of sentences are believed to be the means of verbalization of such concepts in the Russian philology. In this approach, a structural scheme is interpreted as a language sign designatum of which serves a typical proposition, or (in other terminology) a syntactic concept and significant is presented by word forms constituting a structural scheme (Popova, 2009; Fedorov, 2013 and others).

Given the above, we consider a typical proposition of the 'state of nature' as a unit of conceptualized knowledge, linguistic signs of which are structural schemes of simple sentences. On the basis of the thesis of informative adequacy of schemes, taking into account the community of lexical filling, we singled out 19 structural schemes, representing the concept of the 'state of nature' in the Russian language. Pronominal words (pronouns and pronominal adverbs), concrete and abstract verbal lexis, case indicators were primarily used as the meta-language for the descriptions of schemes.

In accordance with the principle of specialty, that is, intended or unintended schemes for verbalization of the 'state of nature' concept in the Russian language, all the schemes were differentiated into two large groups: specialized (there are eight of them: "where is it how", "where does it go itself", "where does it of what", "where does it act what with/where from/where to", "where does it cover what (Accusative case) what with", "where does it move what (Accusative case) from/to", "where does it create what (Accusative case, Genitive case)", "where does it destroy what (Accusative case)" and unspecialized (there are eleven of them, "where is there which state", "what is staying in which state", "what is it how as to the state", "what is which as to the state", "what is in which state", "what is full of which state/with which state", "what is immersing in which state", "what is immersed in which state", "where there is no which state", "what is being covered with what", "what is covered with what"). Specialized structural schemes underlie mononuclear impersonal sentences; they are of interest not only for domestic but also for foreign researchers [Galkina-Fedoruk, 1958; Russian Grammar, 1980; Davies, 2005; Dolin, 2008 et al.]. For example: V vozdukhe kholodalo s kazhdym dnem ["In the air it has been getting colder every day"] (Ivanov, Vechnyy zov [Eternal Call]) (the scheme "where is it happening itself"); V lesu bylo sumrachno ["It was dark in the forest"] (Paustovsky. Severnaya povest [The North Story]) (the scheme "where is it how") and others.

Non-specialized structural schemes underlie two-part and one-part nominative sentences. For example: Vozdukh pyanyy ["The air is drunk"] (Tolstoy, Khozhdenie po mukam [The Road to Calvary]) (the scheme "what is in which state"); Bezvetrie ["There is no wind"] (Tolstoy, Petr Pervyy [Peter the Great]) (the scheme "where is it how") and others. Nonspecialized schemes are intended at verbalization of the concepts of "being of the object", "otherness of the object", "being of the characteristic of the object", "non-existence of the object", "self-movement of the agent", "content of the object", "the cover of the object". Their use in the Russian language to represent the 'state of nature' concept is possible due to a specific lexical content of the constitutive component of schemes - the predicate which is represented by lexemes with the seme of 'state'. For example, the structural scheme "where is it which state" is a modification of the structural scheme "who/what is where" which verbalizes the concept of 'being an object' (a sentence of the kind: Noch. Osveshchennaya magistral ["It is night. It is an illuminated highway"]). The scheme "who/what is where" is used to represent the 'state of nature' concept due to the fact that the position of the object of being in the speech realization of 
the scheme is filled with the lexemes containing the seme of the 'state'. For example: - Ekaya lyutaya pogoda, - zametil Yegor ["What fierce weather," said Yegor] (Zadornov. Amur-batyushka [Amur Father]); Dushno, - skazal on. - Zhara... ["It is stuffy, he said. - It is heat ..."] (Tolstoy. Petr Pervyy [Peter the Great]).

The content of the 'state of nature' concept is constituted by a number of cognitive features identified by the compositional analysis of the structural schemes, especially their lexical content and speech realization. In total we singled out 25 such signs: 1. spontaneity (brightness index - 100), 2. perceptivity (brightness index - 91), 3. temporariness (brightness index - 78), 4. localization (brightness index - 67), 5. glow (brightness index -32), 6. intensity (brightness index - 28), 7. state of phase (brightness index - 25), 8. temperature (brightness index - 17), 9. sonority (brightness index -14), 10. distribution (brightness index - 11), 11. anthropomorphism (brightness index - 8), 12. cover (brightness index - 5), 13. the iterative process (brightness index - 4.5), 14. causativity (brightness index-3.4), 15. patientivity (brightness index - 3.2), 16. filling (brightness index-3.1), 17. movement (brightness index - 2.9), 18. modification (brightness index-2.5), 19. colorativity (brightness index - 18), 20. directivity (brightness index - 1.6), 22. saturation (brightness index - 1.5), 23. being an object (brightness index - 1), 24. zoomorphism (brightness index -0.9 ) 25. optativity (brightness index -0.3 ).

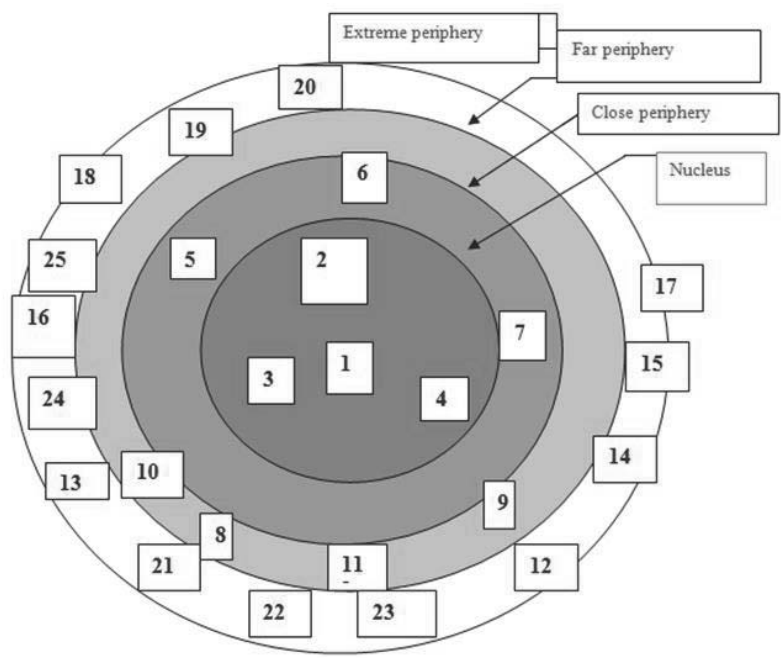

\section{Figure 1.}

As we can see in Figure 1, the content of the 'state of nature' concept is structured as a field with significant nuclear and peripheral areas. The boundary between the zones of the field structure is drawn through the line of the largest decline frequency of implementations, and the brightness index of each cognitive characteristic is defined as the ratio of the number of statements structured according to one or another scheme, objectifying the given characteristic, to the total number of sample statements, which are based on specialized structural schemes, multiplied by 100.

Singling out the features 'spontaneity', 'perceptivity', 'glow', 'localization', 'temperature', 'cover', 'sonority', 'movement', 'filling', 'distribution', 'modification', 'colorativity', 'saturation' in the content of the 'state of nature' concept is determined by the representation of constituents of specialized structural schemes - predicatives - by the words of category of state, impersonal verbs, personal verbs in the impersonal usage with the meaning of states perceptually perceived by the Observer (of the kind of it is calm, it is light, it is getting dusk, it is getting colder and others.) and subjectives - by the lexemes with spatial meaning (such as, V stepi bylo tikho i temno ["It was calm and dark in the steppe"] (Gorky. Starukha Izergil [Old Woman Izergil]) (the scheme "where is it how"); Vezde pakhlo cheremukhoy ["It smelled of hackcherry everywhere"] (Prishvin. Kalendar prirody [Calendar of Nature]) (scheme "where does it of what").

The cognitive characteristics of 'patientivity', 'being an object' and 'directivity' are also associated with a composition of the specialized structural schemes. The first characteristic is due to the fact that the carrier of the state in the structural scheme "it covers what (Accusative case) what with" is expressed by word forms (nouns in the Accusative case or their substitutes - pronouns) with the meaning of the part of natural space, a natural object characterized 
according to the state caused by the impact of any natural forces. We call it "patient of 'inanimate natural substance"' which is affected by the object - spontaneous causer. For example: ... Gorizont na zapade i na yuge zavoloklo dymnoy mgloy ["... The horizon in the west and in the south was beclouded with the smoky haze"] (Tolstoy. Khozhdenie po mukam [The Road to Calvary]); Nebo sovsem zatyanulo tuchami... ["The sky was completely overcast with clouds..."] (Amosov. Golosa Vremen [Voices of Times]). The second feature - 'being an object' - is updated in the content of the 'state of nature' concept due to the presence of the third component in the schemes "where does it move what (Accusative case) where from/to", "where does it create what (Accusative case, Genitive case)", "where does it destroy what (Accusative case, Genitive case)". The third component represents an object exposed to the impact (moving, creation or destruction), and marked by Accusative or Genitive case of a noun. For example: ...Krugom snegu namelo... ["All around the snow piled up"] (Shmelev. Chelovek iz Restorana [The man from the Restaurant]) (the scheme "where does it create what (Accusative case, Genitive case)"). The characteristic 'directivity' is shown by the regular objectivation of the component "point of departure/destination of moving of the state" in the speech realization of structural schemes "where does it act what with/where from" and "where does it move what (Accusative case) where from/to". For example: Grozu snosilo k Mertvomu moryu [The thunder was being carried away to the Dead Sea"] (Bulgakov. Master i Margarita [The Master and Margarita]) (the scheme "where does it move what (Accusative case) where from/to"); ... Iz nedavno prosnuvshikhsya dolin veyalo dushistoy svezhestyu ... ["From the newly awakened valleys fragrant freshness exuded..."] (Turgenev. Zapiski okhotnika [Hunter's Notes]) (the scheme "where does it act what with where from/to").

The presence of sentences with the 'state of nature' semantics, realizing the metaphorical transfer from the state of the living creature to the state of nature, allows revealing such feature as 'anthropomorphism' in the content of the concept the 'state of nature'. For example: ... V pole bylo grustno, pusto, kholodno, neprivetlivo ... ["It was sad, empty, cold, uninviting in the field..."] (Bunin. Zhyzn Arsyenyeva [Arsenyev's Life]); Prishli v roshchu. Tam bylo pusto i pechalno ["They came to the grove. It was empty and sad there"] (Panova. Seryozha [Seryozha]) (examples are based on the scheme "where is it how"). Two more characteristics, 'zoomorphism' and 'emotivity', are associated with the characteristic 'anthropomorphism'. The 'zoomorphism' characteristics has a low brightness index. The sentences realizing the sound referring to the state of nature are described by analogy with the sounds made by birds and animals: vyt' "howl" (a wolf), revet' "roar" (the bear), ukhat' "hoot" (owl): Gde-to daleko bushevala groza, gde-to eshche ukhalo i grokhotalo... ["The storm was raging somewhere far away; it hooted and roared somewhere else..."] (Panteleyev. Lyonka Panteleyev) (the scheme "where does it happen itself"). The characteristic "emotiveness" is demonstrated by the lexemes denoting "emotional-volitional state", marking the predicatives of structured schemes. For example: Bylo sumrachno, tikho, sero $i$ pechalno ["It was gloomy, silent, gray and sad"] (Korolenko. Posledniy Lutsch [The Last Ray]) (the scheme "where it is how").

The characteristics 'temporality', 'iterativity', 'causativity' are connected with the introduction of lexemes with time and causality meanings in the statements with the speech implementation of schemes. For example: Zoryami kholodeet krepko ["At the dawns (a determiner with the meaning of time and frequency) it grows cold hard] (Shmelev. Solntse Mertvykh [The Sun of the Dead]) (the scheme "where does it happen itself"); Na dvore bylo temno ot nochi $i$ sero ot tumana ["It was dark because of the night and the gray because of the fog"] (determiners with the meaning of reason) (Bunin. Bozhye Derevo [God's Tree]) (the scheme "where it is how").

The cognitive characteristic 'phasicity' is implemented with the structural and semantic (phasic) modification of specialized structural schemes. For example: Cherez polchasa nastupil vecher. Stalo sovershenno temno. ["In half an hour later it was evening. It got completely dark'] (the transition from one state to another) (Pasternak. Doctor Zhivago) (the scheme "where is it how"); V more nachinaet belet ["It begins to turn white in the sea"] ('the initial phase of the state') (Shmelev. Solntse Mertvykh [The Sun of the Dead]) (the scheme "where does it happen itself").

The cognitive characteristic 'optativity' is demonstrated by the presence of the subjunctive verb forms expressing the desirability or undesirability of a state of nature in the statements. For example: -Kak by segodnya ne zasvezhelo! $K$ tomu idet-s. ["It may become fresh today! - It looks like this"] (Stanyukovich. Passazhirka [Passenger]) (the scheme "where does it happen itself"). And the characteristic 'intensity' is revealed in statements due to the introduction of the explicants with the meaning of the state explication intensity into the statements. For example: Pod vodoy bylo svetlo $i$ slabo solnechno ["It was bright and slightly sunny under the water"] (Grekova. Na Ispytaniyakh [During the Tests]) (the scheme "where is it how").

The enumerated cognitive features of the concept, in our opinion, affect both the component structure of the structural schemes, and the specifics of their lexical filling, as well as the possibility to use structural schemes representatives of some concepts to demonstrate others. The above theoretical development of the field content model of the 'state of nature' concept in general, can be applicable to a number of other concepts, verbalized by syntactic units.

The problem of describing the structural and semantic organization of the sentence has not only a linguo cognitive 
aspect related to the presentation of the concept in the language by the majority of the distinguished structural schemes, but also linguo culturological aspect due to the development of the theory of linguistic worldview and the idea about the reflection of its specifics in the national mentality. Currently, the status of the concept of the "linguistic worldview" and the possibility of its fixing by means of language has not been solved (Sériot 2004; Kolshansky 2006; Pavlova and Bezrodnyj, 2010 and others). We associate linguo culturological aspect of the linguistic worldview analysis through the prism of the syntactical elements with ideas of A. Wierzbicka and representatives of Novomoskovskaya school of conceptual analysis of the possibility to form a linguistic worldview by the system of key concepts and invariant key ideas (Wierzbicka 1996, 1997, 1998, 2000; Zaliznyak, Levontina and Shmelev, 2012 and others).

This aspect of the study of Russian linguistic worldview can be used to describe a fragment of 'nature - the state of nature'. A few of these key ideas, in varying degrees realized in the statements with the semantics of 'the state of nature', have been singled out in the analysis of the actual language material. The most productive are the ideas of animation of nature and the dichotomy of states of nature. So, the idea of the nature animation is "included" into the metaphorical statements with the 'state of nature' semantics through the implementation of sustainable transfer of the "state of the living creature (usually a man) to the "state of nature". It provides functioning of predicate lexemes denoting various physiological, psycho-emotional states of living beings in the speech implementation of structural schemes of sentences with the 'state of nature' semantics. Moreover, in our opinion, it is this idea that determines the use of structural schemes intended for naming the concept of "physiological and psychological state of the animate subject" as markers of the concept of the "state of nature". For example, a scheme "what (Accusative case) is sick": Prirodu mutit... Syro, kholodno $i$ zhutko...["The nature is sick... It is damp, cold and fearful ..."] (Chekhov. Son [Dream]); the scheme "to what is it how": Kazalos, chto dazhe prirode bylo skuchno ["It seemed that even nature was bored"] (Sollogub. Tarantas [A Banger]) and others.

The idea of dichotomy of states of nature is manifested in almost all groups of statements classified by the method of state demonstration by marking polar juxtaposed states of nature: states of belo and cherno "white" and "black", zharko and kholodno "hot" and "cold", svetlo and temno "light" and "dark", and others. For example: Cherno i zharko vokrug. ["It is black and hot around"] (Slonimsky. Andrey Korobitsyn); Na dvore - belo. ["It is white in the yard"...] (Tolstoy. Petr Pervyi [Peter the Great]) (the examples are based on the scheme "where is it how"). According to the ways of being in the state in the Russian language, we have identified total of ten groups of statements. The frequency of their implementation is presented in the following linear bar chart:

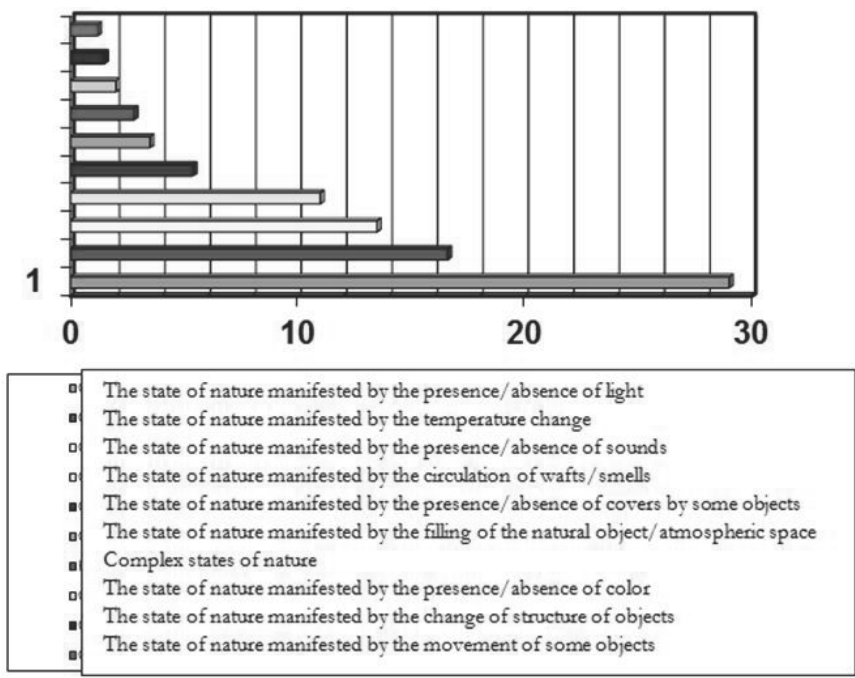

\section{Figure 2.}

The idea of natural cyclical changes, winter sleep, stagnation and spring and summer revival, resurrection, is connected with the idea of animation of nature. For example: Nizkoroslyy les na obryvakh i skatakh byl redok, dremal i skupo ronyal melkiye zheltyye listia ["The scrub forest on the cliffs and slopes was rare, drowsing and sparingly dropped small yellow 
leaves'] (Bunin. Malenkiy roman [Small Novel]); Poveyalo s morya i s polya teplom... Zemlya pokrylas novoy travoy, na dereviakh zazeleneli novyye listia. Priroda voskresla...["It smelled like warmth from the sea and the field. The ground was covered with the new grass, the trees turned green with new leaves. The nature revived ...'] (Chekhov. Nenuzhnaya Pobeda [The Unnecessary Victory]) (the examples in bold are based on the scheme "what is in which state").

The idea of the integrity of nature and man allows, firstly, considering the figure of the Observer cognizing the world as the central one, and secondly, creating a complete classification of the statements with the 'state of nature' semantics, taking into account the difference in the way the perception of the state by the Observer (visual, tactile, olfactory, auditory). This idea also leads to the existence of multimodal utterances (Bylo znoyno i tikho ["It was sultry and quiet"] (Tolstoy. Aelita) (the scheme "where is it how")); schemes, implementing phenomena of synesthesia (Pokoilas gulkaya moroznaya tishina ["The echoing frosty silence was reposing"] (Sholokhov. Tikhiy Don [And Quiet Flows the Don]) (the scheme "where is there which state")) and synesthesia (...Stalo bystro $i$ kak-to neverno, trevozhno temnet ot nadvigayvshchikhsya s vostoka tuch... ["and it was getting dark quickly and somehow wrong, anxiously from the clouds impending in the east ..."] (Bunin. Zhizn Arsenyeva [The Life of Arseniev]) (the scheme "where does it happen itself")); metaphoric statements, which describe the human condition similar to the state of nature (Sumrachno bylo i na dushe $u$ knyazya ["It was gloomy in the Prince's heart, too"] (Ivanov. Serdtse Parmy [The heart of Parma]) (the scheme "who has which condition where")).

The ideas of shelter and spatial infinity are present in limited groups of statements with 'state of nature' semantics, in those ones which are formed by the predicates of state uyutno [cozily] and prostorno [spaciously]. In fact, these two contradictory ideas "peacefully coexist" in the Russian language picture of the world. The idea of shelter suggests small, fenced natural space for the Observer's "peace of mind", and the idea of the infinity of space implies, on the contrary, the vast, unrestricted natural space. For example, cf: ...V smeshannykh lesakh i roshchakh uyutno i svetlo... [It is bright and welcoming in mixed forests and groves] (Bubennov. Belaya Bereza [The White Birch]); V nebesakh bylo prostorno... [In heaven it was spacious ...] (Astafyev. Oberton [The Overtone]) (the examples are based on the scheme "where is it how".

Metaphoric expressions, carrying out the transfer of a living being state into the state of nature, play a special role in identifying the totality of these key ideas. This is due to the fact that the anthropomorphic metaphor, being part of an ancient mechanism of reality perception, captures the peculiarities of the relationship and interaction of the ethnicity with the world around and passes them on from generation to generation in "rigid" forms. For example, the ideas as identified previously, realized in the Russian language picture of the world of the $19^{\text {th }}-20^{\text {th }}$ centuries, have their roots in ancient times and reflect the archaic beliefs of the Slavs about the nature: the perception of nature as a living being, understanding of the world in binary systems, understanding of time, not as a linearly running, but as a cyclical time, the interpretation of changes occurring in nature as immanent.

\section{Summary}

Thus, the analysis of the Russian language picture of the world as related to the syntactic units is currently under development and it is carried out in Russian studies in two main directions. The linguo-cognitive direction is connected with the study of concepts and syntactic means of their verbalization - structural schemes, and linguo-culturological with the attempts to examine the structural and semantic organization of sentences through the prism of the national culture to save the accentuation of ethnic mentality in grammatical structure.

\section{Conclusions}

In the course of the performed research, we came to the conclusion that can be formulated as follows: typical proposition of the 'state of nature' is a unit of storing knowledge about categorized and classified situations of extra linguistic reality in human consciousness; the signs-representatives of the 'state of nature' concept in the Russian language serve a set of structural schemes of sentences which do not constitute a homogeneous group according to the intention or non-intention of the schemes for the verbalization of the concept mentioned; the fragment of the Russian language picture of the world, retaining the states of nature, is consolidated by a set of key ideas that date back to archaic notions of the Slavs about the nature and are implemented in varying degrees in the statements with the 'state of nature' semantics.

\section{References}

Bodeh, S. (2004). Reprezentatsiya sostoyaniya, sobytiya, kauzal'nosti i dejstviya [The Represantation of the State, Event, Causativity and Action]. Voprosy psikholingvistiki, No.2, (pp. 6-18). [in Russian]. 
Boldyrev, N. N. (2002). Kognitivnaya semantika. Kurs lektsiy po angliyskoy filologii [Cognitive Semantics. Course of Lectures on English Philology]. - Tambov: Izdatelstvo TGU im. G. R. Derzhavina. (pp. 36-38) [in Russian].

Dolin, Yu. T. (2008). Voprosy teorii odnosostavnogo predlozheniya (na materiale russkogo yazyka) [Theoretical Issues on One-member Sentence (as exemplified in the Russian language)]. - Orenburg: IPK GOU OGU. (P. 129). [in Russian].

Fedorov, V. A. (2013). Natsionalnaya spetsifika sintaksicheskikh kontseptov [National Specificity of Syntactic Concepts]: dis. ...dokt. filol. nauk. - Voronezh, Voronezhskiy gosudarstvennyy universitet. (P. 380). [in Russian].

Galkina-Fedoruk, E. M. (1958). Bezlichnye predlozheniya v sovremennom russkom yazyke [Impersonal Sentences in the Modern Russian Language]. - Moscow: Moskow State University Press. (P. 331). [in Russian].

Kolshanskiy, G. V. (2006). Obyektivnaya kartina mira v poznanii i yazyke [Objective View of the World in Cognition and Language]. / Otv. red. Shakhnarovich, A.M. - Moscow: KomKniga. (P. 93). [in Russian].

Norman, B. Yu. (2013). Kognitivnyy sintaksis russkogo yazyka [Cognitive Syntax of the Russian Language]. - Moscow: FLINTA: (p. 57) [in Russian].

Popova, Z. D. (2009). Sintaksicheskaya sistema russkogo yazyka v svete teorii sintaksicheskikh kontseptov [The Syntactic System of the Russian Language in Relation to the Theory of Syntactic Concepts]. - Voronezh: Istoki. (P. 209). [in Russian].

Rzhepyanskaya, I. V. (2010). Russkoe narodnoe tvorchestvo v stanovlenii nravstvennoy kultury Drevney Rusi [Russian Folk Art in the Formation of Moral Culture of Ancient Rus]. - Moscow: KRASAND. (P. 200).[in Russian]

Russkaya grammatika [Russian Grammar]. Vol. 2. Sintaksis [Syntax] (1980). - Moscow: Nauka. (P. 710). [in Russian].

Yakovleva, I.N. (2004). Semanticheskaya kategoriya sostoyaniya i sredstva ee realizatsii (na materiale russkogo i anglijskogo yazykov) [The Semantic Category of State and the Means of its Realization (as exemplified in the Russian and English languages]: avtoref. dis. ...kand. filol. nauk. - Voronezh: VGU. [in Russian]

Zaliznyak, A.A., Levonina, I.B., Shmelev, A.D. (2012). Konstanty i peremennye russkoy yazykovoy kartiny mira [Constants and Variables of the Russian Language Worldview]. - Moscow: Yazyki slavyanskikh kultur. (P. 696). [in Russian].

Davies, L. E. (2005). A Construction-Grammatical Analysis of Impersonalization in Russian: dis. ...Ph.D. - Princeton: Princeton University.

Jackendoff, R. (1983). Semantics and Cognition. - Cambridge: MIT Press.

Le Ny, J. F. (1979). La Sémantique Psychologique. - Paris: Presses Universitaires de France.

Pavlova A., Bezrodnyy M. (2010). How to Catch a Unicorn? The Image of the Russian Language from Lomonosov to Wierzbicka. /I Toronto Slavic Quarterly, TSQ No.32. Retrieved from: www.sites.utoronto.ca/tsq/32/index.shtml.

Searle, J.R. (1983). Intentionality. - Cambridge: Cambridge University Press.

Sériot, P. (2005). Oxymore ou malentendu? Le relativisme universaliste de la métalangue sémantique naturelle universelle d'Anna Wierzbicka. Cahiers Ferdinand de Saussure. No.57, pp. 23-43.

Wierzbicka, A. (1996). Semantics: Primes and Universals. Oxford: Oxford University Press.

Wierzbicka, A. (1997). Understanding Cultures through their Key Words: English, Russian, Polish, German, and Japanese. N. Y. Oxford University Press.

Wierzbicka, A. (1998). "Sadness» and "Anger» in Russian: the Non-universality of the So-called «Basic Human Emotions». Speaking of Emotions: Conceptualisation and Expression, Eds., Athanasiadou, A. and Tabakowska, E. Berlin: Mouton de Gruyter, pp. 3-28.

Wierzbicka, A. (2000). Lexical Prototypes as a Universal Basis for Cross-linguistic Identification of «Parts of Speech». Approaches to the Typology of Parts of Speech, Eds., Vogel, Petra M. and Comrie, B. Berlin; N. Y.: Mouton de Gruyter, pp. 285-317. 